\title{
Do cover crops enhance soil greenhouse gas losses during high emission moments under temperate Central Europe conditions?
}

\section{Erhöhen Zwischenfrüchte Treibhausgasemissionen während kritischer Emissionszeitpunkte unter zentraleuropäischen gemäßigten Klimabedingungen?}

\author{
Gernot Bodner ${ }^{1}$, Axel Mentler ${ }^{2}$, Andreas Klik ${ }^{3}$, Hans-Peter Kaul ${ }^{1}$, Sophie Zechmeister-Boltenstern ${ }^{2}$
}

\author{
${ }^{1}$ Department of Crop Sciences, Division of Agronomy, University of Natural Resources and Life Sciences (BOKU), Konrad-Lorenz-Straße 24, \\ 3430 Tulln an der Donau, Austria \\ ${ }^{2}$ Department of Forest and Soil Sciences, Institute of Soil Sciences, University of Natural Resources and Life Sciences (BOKU), Peter-Jordan- \\ Straße 32, 1180 Vienna, Austria \\ ${ }^{3}$ Department of Water, Atmosphere and Environment, Institute of Hydraulics and Rural Water Management, University of Natural Resources \\ and Life Sciences (BOKU), Muthgasse 18, 1190 Vienna, Austria \\ Corresponding author: gernot.bodner@boku.ac.at
}

Received: 11 October 2017, received in revised form: 30 November 2017, accepted: 11 December 2017

\begin{abstract}
Summary
Cover cropping is a key agro-environmental measure in Europe. Cover crops may reduce $\mathrm{N}_{2} \mathrm{O}$ emissions by reducing soil nitrate content, while easily decomposable residues can enhance greenhouse gas losses. In a field study, emissions from the cover cropped fields compared to the fallow at two climatically different sites (semi-arid vs. humid) in Austria were measured with closed chambers and different driving factors were studied. The height of post-cover crop emissions was compared to gaseous losses during the management operations in the subsequent main crop maize. $\mathrm{N}_{2} \mathrm{O}$ and $\mathrm{CO}_{2}$ emissions following the cover crops were low even at high emission moments compared to the losses induced by the main crop management operations. Highest risk of $\mathrm{N}_{2} \mathrm{O}$ losses was from mustards due to low $\mathrm{C} / \mathrm{N}$ ratio and possibly as a consequence of glucosinolate decomposition. $\mathrm{CO}_{2}$ emissions in the cover cropped plots were generally higher compared to the fallow, indicating an enhanced soil microbiological activity. Dissolved organic carbon was found as a sensitive indicator related to the greenhouse gas emissions. We concluded that the environmental benefits from cover cropping are not achieved at the cost of an enhanced greenhouse gas emission and that pure stands of late sown brassica cover crops should be avoided to prevent any risk of increased $\mathrm{N}_{2} \mathrm{O}$ losses.
\end{abstract}

Keywords: greenhouse gas emissions, cover crops, hot emission moment, dissolved organic carbon, mustard

\section{Zusammenfassung}

Zwischenfruchtbau ist eine wichtige Agrarumweltmaßnahme in Europa. Zwischenfrüchte können Emissionen von $\mathrm{N}_{2} \mathrm{O}$ über die Verringerung des Bodennitratgehaltes reduzieren, während leicht abbaubare Pflanzenrückstände dagegen die Treibhausgasverluste zeitweilig erhöhen können. In einem Feldversuch wurden Treibhausgasemissionen von zwischenfruchtbegrünten Feldern im Vergleich zu Schwarzbrache an zwei klimatisch unterschiedlichen Standorten (semi-arid vs. humid) in Österreich mittels geschlossener Kammern gemessen, sowie verschiedene Einflussfaktoren untersucht. Im Fokus standen dabei Emissionen zu kritischen Zeitpunkten zwischen Spätherbst und Frühling nach Einarbeitung der Zwischenfruchtreste. Die Höhe der Emissionen nach Zwischenfrucht wurde mit gasförmigen Verlusten bei anderen Managementmaßnahmen in der folgenden Hauptfrucht Mais verglichen. Die Emissionen von $\mathrm{N}_{2} \mathrm{O}$ und $\mathrm{CO}_{2}$ nach den Zwischenfrüchten waren selbst zu kritischen Zeitpunkten niedrig im Vergleich zu Verlusten während der Hauptfrucht-Managementmaßnahmen. Die höchsten $\mathrm{N}_{2} \mathrm{O}$-Verluste wurden bei Gelbsenf festgestellt, aufgrund eines engen $\mathrm{C} / \mathrm{N}$-Verhältnisses und möglicherweise als Folge des Abbaus von Glucosinolaten. $\mathrm{CO}_{2}$-Emissionen von den begrünten Parzellen waren im Allgemeinen höher als bei Schwarzbrache, was eine erhöhte mikrobielle Aktivität anzeigt. Gelöster organischer Kohlenstoff erwies sich als sensitiver Indikator für Treibhausgasemissionen. Es lässt sich schlussfolgern, dass die Umweltleistungen des Zwischenfruchtbaus ohne erhöhtes Risiko verstärkter Treibhausgasemissionen erzielt werden und dass spät gesäte Reinbestände von Kreuzblütler-Zwischenfrüchten vermieden werden sollen, um das Risiko von $\mathrm{N}_{2} \mathrm{O}$-Verlusten zu minimieren.

Schlagworte: Treibhausgasemissionen, Zwischenfrüchte, kritische Emissionszeitpunkte, gelöster organischer Kohlenstoff, Gelbsenf 


\section{Introduction}

Cover cropping has become a key management measure to reduce nitrate leaching and soil erosion in intensive crop production (e.g., Wyland et al., 1996; Dabney, 1998; Meyer et al., 1999; Shepherd and Webb, 1999; Hartwig and Ammon, 2002; Logsodon et al., 2002; van Dam, 2006). A new agro-environmental target in the current period of common European agricultural politics is climate change mitigation and adaptation (EU 2013). Estimates by IPCC (2007) and Smith et al. (2008) attribute around $10-12 \%$ of global greenhouse gas emissions to agriculture, with a dominant role for $\mathrm{N}_{2} \mathrm{O}(60-84 \%)$ and $\mathrm{CH}_{4}(50 \%)$ emissions. Soil borne $\mathrm{N}_{2} \mathrm{O}$ emissions are mainly related to $\mathrm{N}$-fertilization, with estimates of about $1.25 \% \pm 1 \%$ of total fertilizer $\mathrm{N}$ lost via $\mathrm{N}_{2} \mathrm{O}$ emission (Moisier et al., 1998). Cover crop uptake of excessive soil $\mathrm{N}$ is therefore expected to contribute to agricultural climate change mitigation (McSwiney et al., 2010). Parkin et al. (2006) evaluated the effect of a rye cover crop on the overall $\mathrm{N}$ balance after pig slurry application and showed that the rye cover crop lowered the cumulative $\mathrm{N}_{2} \mathrm{O}$ emission in case of high manure application. However, other studies reported different outcome. Liebig et al. (2010) and Jarecki et al. (2009) did not find differences in cumulative fluxes of $\mathrm{CO}_{2}, \mathrm{CH}_{4}$, and $\mathrm{N}_{2} \mathrm{O}$ between bare and green-manure (rye) amended soil, while Bavin et al. (2009) showed an increase in $\mathrm{CO}_{2}$ only and $\mathrm{N}_{2} \mathrm{O}$ emissions was not affected by the rye cover crop. Kallenbach et al. (2010) found that both $\mathrm{CO}_{2}$ as well as $\mathrm{N}_{2} \mathrm{O}$ losses from fields with a winter legume cover crop (hairy vetch) increased compared to fallow.

Rosecrance et al. (2000) compared the overall field $\mathrm{N}$-balance including denitrification for rye, rye-vetch and vetch cover crops with fallow. They showed greater potential $\mathrm{N}$ losses from vetch than rye or rye-vetch mixtures due to rapid $\mathrm{N}$-mineralization in conjunction with denitrification and potential leaching, prior to significant $\mathrm{N}$ assimilation by the subsequent main crop. Under tropical conditions in Brazil, Gomes et al. (2009) measured $\mathrm{N}_{2} \mathrm{O}$ emissions in a no-tillage maize system after a grass (Avena strigosa) and different legume cover crops. Legume cover crops caused the highest cumulative emissions, which were directly related to the quantity of $\mathrm{N}$ and inversely related to the lignin: $\mathrm{N}$ ratio of residues. The annual $\mathrm{N}_{2} \mathrm{O}$ emission represented $0.39-0.75 \%$ of total $\mathrm{N}$ provided by the legume cover crops.

Velthof et al. (2002) compared $\mathrm{N}_{2} \mathrm{O}$ emissions from different crop residues and the influence of $\mathrm{NO}_{3}$ addition in an incubation study. Emissions from residues of wheat, maize and barley were neglegible, while total $\mathrm{N}_{2} \mathrm{O}$ emission from white cabbage, Brussels sprouts, mustard, sugar beet residues and broccoli ranged from 0.13 to $14.6 \%$ of the amount of $\mathrm{N}$ added as residue and were higher with additional $\mathrm{NO}_{3}$ than without. The $\mathrm{C} / \mathrm{N}$ ratio of the residue accounted for only $22-34 \%$ and the mineralizable $\mathrm{N}$ content of the residue for $18-74 \%$ of the variance in $\mathrm{N}_{2} \mathrm{O}$ emission. An incubation study with hairy vetch by Aulakh et al. (1991) showed that the losses occurred mainly during the first 10 days after residue addition and were mostly influenced by the additional $\mathrm{C}$ from the incorporated legume crop residues. Thus, the type of cover crop species seems to be decisive to either mitigate or even increase the greenhouse gas losses.

There are only a few field studies focusing on the overwinter emissions between the frost killing of cover crops in late autumn and start of the main crop in subsequent spring. In this period, freezing-thawing and snow melting could lead to critical moments with high nitrous oxide emissions (Hagedorn et al., 2011). A study conducted in Denmark by Petersen et al. (2011) reported slightly higher $\mathrm{N}_{2} \mathrm{O}$ emissions from a cover cropped soil (oilseed radish) after freezing events. Still, emissions during autumn, winter and early spring were generally low. A peak in emissions occurred in spring after tillage and organic fertilizer application. Pattey et al. (2008) investigated $\mathrm{N}_{2} \mathrm{O}$ emissions in a pea-cover crop sequence in Canada with particular regard to spring thawing. Thawing induced emissions were $15 \%$ of the total annual emissions. Also, Wagner-Riddle and Thurtell (1998) studied the effect of thawing on $\mathrm{N}_{2} \mathrm{O}$ emissions in a Canadian field experiment with different management practices. Nitrous oxide emissions between January and April over four years ranged between 0 and $4.8 \mathrm{~kg} \mathrm{~N} \mathrm{ha}^{-1}$. The study indicated that denitrification losses from cover cropped soils strongly depended on hot moments (wetting-drying, freezing-thawing) following residue incorporating.

For Central European conditions, it is therefore suggested that greenhouse gas losses from cover cropped fields are determined by plant species and critical high emission moments after cover crop residue addition to the soil. The objectives of this study were (i) to compare the greenhouse gas emissions from field soil among commonly used cover crops and cover crop mixtures, and (ii) to evaluate the key drivers for gaseous losses between cover crop frost killing in late autumn and start of main crop vegetation period in early spring. The main hypothesis is that cover crops in- 
crease soil $\mathrm{CO}_{2}$ emissions due to an enhanced input of organic residues, while they reduce $\mathrm{N}_{2} \mathrm{O}$ emissions compared to fallow because of reduced nitrate content in surface soil.

\section{Material and methods}

\subsection{Field experiments}

\subsubsection{Experimental locations and setup}

Field experiments were established at two sites with different climatic and pedological conditions. A first experiment was located near Lichtenwörth, Lower Austria ( $47^{\circ}$ $49^{\prime} \mathrm{N}, 16^{\circ} 16^{\prime} \mathrm{O}, 254 \mathrm{mAA}$ ). Lichtenwörth is situated in the Southern Viennese Plain and belongs to the sub-humid climate zone with long-term averages (1971-2000) of rainfall being $599 \mathrm{~mm}$ and mean annual temperature $9.4^{\circ} \mathrm{C}$. The soil is a calcareous chernozem with sandy loam texture and a depth of the A horizon of $60 \mathrm{~cm}$, overlaying a D horizon of coarse fluvial sediments. The soil is characterized by high water permeability and air capacity. The second experimental site was located near Pötting, Upper Austria ( $\left.48^{\circ} 17^{\prime} \mathrm{N}, 13^{\circ} 46^{\prime} \mathrm{O}, 381 \mathrm{mAA}\right)$. Pötting belongs to the humid climate zone influenced by north-eastern Atlantic currents. Geographically, Pötting forms part of the hilly pre-alpine region. Long term average (1971-2000) rainfall is $817 \mathrm{~mm}$, mean annual temperature is $7.9^{\circ} \mathrm{C}$. The soil is a typical stagnosol of silty loam texture and a moderately acidic $\mathrm{pH}$ value. Depth of the A horizon is $25 \mathrm{~cm}$, followed by a $\mathrm{P}$ horizon of $40 \mathrm{~cm}$, which is periodically water saturated, particularly in spring, due to low permeability of the underlying S1 and S2 horizons.

Experimental factors included (i) cover cropping vs. bare soil, and (ii) addition of organic fertilizer $\left(30 \mathrm{~kg} \mathrm{ha}^{-1} \mathrm{~N}\right)$ vs. no fertilization. Four cover crop treatments were established, being (a) mustard (Pötting: Sinapis alba L.; Lichtenwörth: Brassica juncea (L.) Czern.; seeding rate $15 \mathrm{~kg}$ $\left.\mathrm{ha}^{-1}\right)(\mathrm{b})$ a commercially available mixture of mustard (Sinapis alba L.; $3 \mathrm{~kg} \mathrm{ha}^{-1}$ ) and phacelia (Phacelia Juss.; $7 \mathrm{~kg}$ $\mathrm{ha}^{-1}$ ), (c) a mixture of cress (Lepidium sativum L.; $2 \mathrm{~kg}$ $\mathrm{ha}^{-1}$ ), Mungo (Guizotia abyssinica Cass.; $1.5 \mathrm{~kg} \mathrm{ha}^{-1}$ ) and oilseed radish (Raphanus raphanistrum L.; $4 \mathrm{~kg} \mathrm{ha}^{-1}$ ), and (d) a commercially available mixture without brassica species and containing Alexandrian clover (Trifolium alexandrinum L.; $\left.8 \mathrm{~kg} \mathrm{ha}^{-1}\right)$ as legume, Mungo (1.5 $\left.\mathrm{kg} \mathrm{ha}^{-1}\right)$ and phacelia $\left(2.5 \mathrm{~kg} \mathrm{ha}^{-1}\right)$. Mustard is the most common cover crop species in Austria, while species mixtures are promoted by the national agro-environmental programme to increase biodiversity and environmental benefits from cover cropping. Organic fertilization of cover crops is a common practice in regions with animal husbandry (Pötting, pig slurry) as well as biogas production (Lichtenwörth, biogas slurry). The total amount of $\mathrm{N}$ applied to the fertilized plots at both sides was $30 \mathrm{~kg} \mathrm{ha}^{-1}$ before cover crop seeding. Experiments were established on the farmer's fields to properly reflect the emissions from common agricultural management practices. Cover crops were sown on $25^{\text {th }}$ of July following the harvest of the preceding cereal crop. In Pötting, the sowing of mustard (Sinapis alba L.) was delayed by two weeks to avoid day length-induced premature flowering. In Lichtenwörth, the mustard species Brassica juncea with later flowering time was chosen and seeding of all variants was done at the same time. The experimental plots had a size of $60 \mathrm{~m}$ length and $6 \mathrm{~m}$ width $\left(360 \mathrm{~m}^{2}\right)$. In total, 10 plots ( 5 soil cover treatments $\times 2$ fertilization treatments) were established. Measurements were done along a line transect with three equally spaced measurements per plot ( $2 \mathrm{~m}$ distance), resulting in a total number of 30 sampling points per site.

Figure 1 shows the monthly averages of precipitation and temperature for the experimental time as well as the previous cover crop growing period.

\subsubsection{Environmental conditions}

At Pötting, the sum of rainfall between July 2012 to April 2013 was slightly lower $(623 \mathrm{~mm})$ compared to the longterm average $(648 \mathrm{~mm})$. At Lichtenwörth, on the contrary, there was substantially higher total precipitation $(577 \mathrm{~mm})$ compared to the long-term average $(447 \mathrm{~mm})$ which was mainly due to very high rainfall in July 2012. July rainfall is crucial for cover crop establishment, particularly in subhumid regions with higher probability of summer drought that might delay cover crop emergence.

For greenhouse gas emissions, both soil temperature and soil water content are crucial environmental parameters. These parameters were measured in the topsoil $(0-5 \mathrm{~cm}$ depth) simultaneously with gas sampling (cf. green arrows in Figure 1). As expected, the soil temperature was generally lower, while the water content was higher at the humid compared to the sub-humid site. At Pötting, the soil temperatures ranged from a minimum of $6.1 \pm 0.4^{\circ} \mathrm{C}$ in February 2013 to a maximum of $14.6 \pm 0.3^{\circ} \mathrm{C}$ in March 2013. In November 2012, the soil temperature was $7.0 \pm$ $0.4^{\circ} \mathrm{C}$. Soil water content ranged from a minimum of 31.4 $\pm 3.0 \%$ in November 2012 to a maximum of $41.7 \pm 2.3 \%$ in March 2013. In February 2013, the soil water content was $39.4 \pm 3.0 \%$. This corresponded to average water filled 
porosities between $62.9 \%$ and $83.3 \%$. At Lichtenwörth, the minimum of soil temperature was also registered in February $2013\left(7.1 \pm 0.4^{\circ} \mathrm{C}\right)$ and the maximum in March $2013\left(16.7 \pm 1.6^{\circ} \mathrm{C}\right)$. Soil temperature in November was $9.7 \pm 0.2^{\circ} \mathrm{C}$. The range of soil water content at Lichtenwörth was between $24.5 \pm 2.9 \%$ in November 2012 and $28.7 \pm 3.1 \%$ in February 2013. In March 2013, the soil water content was $26.3 \pm 3.1 \%$. The corresponding average water filled porosities were $46.1 \%, 55.3 \%$ and $50.6 \%$ respectively.

\subsection{Measurements}

Measured parameters comprised cover crop dry matter and $\mathrm{C} / \mathrm{N}$ ratio, greenhouse gas emissions $\left(\mathrm{CO}_{2}, \mathrm{~N}_{2} \mathrm{O}\right)$, soil mineral $\mathrm{N}\left(\mathrm{NO}_{3}^{-}\right.$and $\mathrm{NH}_{4}^{+}$), dissolved organic carbon, soil moisture and soil temperature (Table 1).

Aboveground biomass samples were taken on $16^{\text {th }}$ November 2012 from one square meter, pre-dried at $50^{\circ} \mathrm{C}$ and thereafter dried for 24 hours at $105^{\circ} \mathrm{C}$ to constant dry weight. After weighing, the samples were milled and analyzed for carbon and nitrogen content using a Carlo Elba CNS Elemental analyzer.

Soil greenhouse gas emissions were measured on three dates. The first sampling was done in late autumn after a short frost period $\left(16-18^{\text {th }}\right.$ November 2012$)$ terminating most plants in order to capture immediate effects from dead leaf and stem addition to soil before winter. The second sampling was done during a period of temporary soil thawing over winter, while the third sampling date coincided with snow melting in March 2013. These sampling periods were considered hot moments (fresh residue addition, freezing-thawing, snow melt with high soil water content) for potential gas emissions. In a sub- set (mustard, legume mixture, fallow; fertilized plots), at the humid (high emission) site, the Pötting measurements were continued until the end of June to obtain comparative values of main crop related emissions (tillage, sowing, $\mathrm{N}$-fertilization). All measurements were done using the closed chamber method (e.g., Rochette et al., 1992) with soil inserted PVC cylinders $(10 \mathrm{~cm}$ height, $20 \mathrm{~cm}$ diameter, insertion depth $3 \mathrm{~cm}$ ). Cylinders were closed airtight with a lid containing a rubber septum for gas sampling via a syringe ( $30 \mathrm{ml}$ sampling volume). Gas samples were taken immediately after closing the chamber (initial concentration), after 15 and 45 minutes and injected in evacuated cups. Analysis of trace gas concentration $\left(\mathrm{CO}_{2}, \mathrm{~N}_{2} \mathrm{O}\right.$ and $\mathrm{CH}_{4}$ ) was done by gas chromatography with a 6890 N GCSystem (Agilent, Santa Clara, CA, USA) connected to an automatic headspace-sample injection system (Dani HSS 86.50 Dani, Cologno Monzese, Italy). Gas flux ( $\mu \mathrm{g}$ resp. $\mathrm{mg} \mathrm{m}^{-2} \mathrm{~h}^{-1}$ ) was then calculated from the change in gas concentration over time.

Soil parameters related to the greenhouse gas formation were measured in the upper soil layer $(0-5 \mathrm{~cm})$ at the time of gas sampling. Soil physical variables comprised water content and temperature (Vitel Hydra Probe). Soil chemical parameters were mineral $\mathrm{N}\left(\mathrm{NO}_{3}, \mathrm{NH}_{4}\right.$; ÖNORM L1091) and dissolved organic carbon (DOC). DOC was determined for selected sampling points only due to the limited analytical capacity. A mixed sample (mixture of three replicate samples; 10 samples per site) of each treatment was taken immediately after the cover crop vegetation period (first gas sampling date) expecting most evident differentiation in DOC. A second set of DOC analysis was made for the measurement dates with the highest $\mathrm{N}_{2} \mathrm{O}$ emissions at each site, that is, $1^{\text {st }}$ February 2013 at Lichtenwörth and $7^{\text {th }}$ March 2013 at Pötting. Again, a mixed

Table 1. Overview of measured parameters, methods and sampling dates

Tabelle 1. Überblick über die gemessenen Parameter, die Methoden und Beprobungstermine

\begin{tabular}{lll}
\hline Parameter & Method & Sampling date $^{+}$ \\
\hline Aboveground biomass & Dry matter at $105^{\circ} \mathrm{C}$ & 14 November 2012 \\
$\mathrm{CN}$ ratio & CNS analyzer & \\
$\mathrm{CO}_{2}, \mathrm{~N}_{2} \mathrm{O}$ & Closed chamber method & 22 November 2012, 1 February 2013, 6 March 2013 \\
Soil mineral N & Photometric & 22 November 2012, 1 February 2013, 6 March 2013 \\
DOC & Photometric & 22 November 2012, 1 February 2013, 6 March 2013 \\
Soil water content & Capacitance & 22 November 2012, 1 February 2013, 6 March 2013 \\
Soil temperature & Thermistor & 22 November 2012, 1 February 2013, 6 March 2013 \\
\hline
\end{tabular}

+Sampling dates at the two sites were \pm 2 days.

${ }^{+}$DOC was measured from a mixed soil sample of three replicates. 
sample for each treatment was analyzed. Analysis was done by infrared spectroscopy after the extraction of the samples by deionized water (Brandstätter et al., 1996).

\subsection{Statistical analysis}

Samples were taken along a line transect with three replicate sampling points in each plot equally spaced at a 2 -meter distance. All parameters were sampled at the same position with only small shifts in the longitudinal direction in case of destructive sampling. We first tested spatial correlation (trends) between the data points via autocorrelation analysis. If no spatial correlation was identified, the three samples per plot were considered random replicates and analysis of variance was performed to test for significant treatment effects. In case of spatial trends, further geo-statistical methods would be applied for data analysis.

Generally, the auto-correlograms did not reveal any spatial trend in the measured parameters as exemplified by Figure 2 for $\mathrm{N}_{2} \mathrm{O}$. In case of greenhouse gas emissions, it is well known that emissions are frequently related to soil micro-sites (e.g., Parkin, 1987) with small scale variabil-

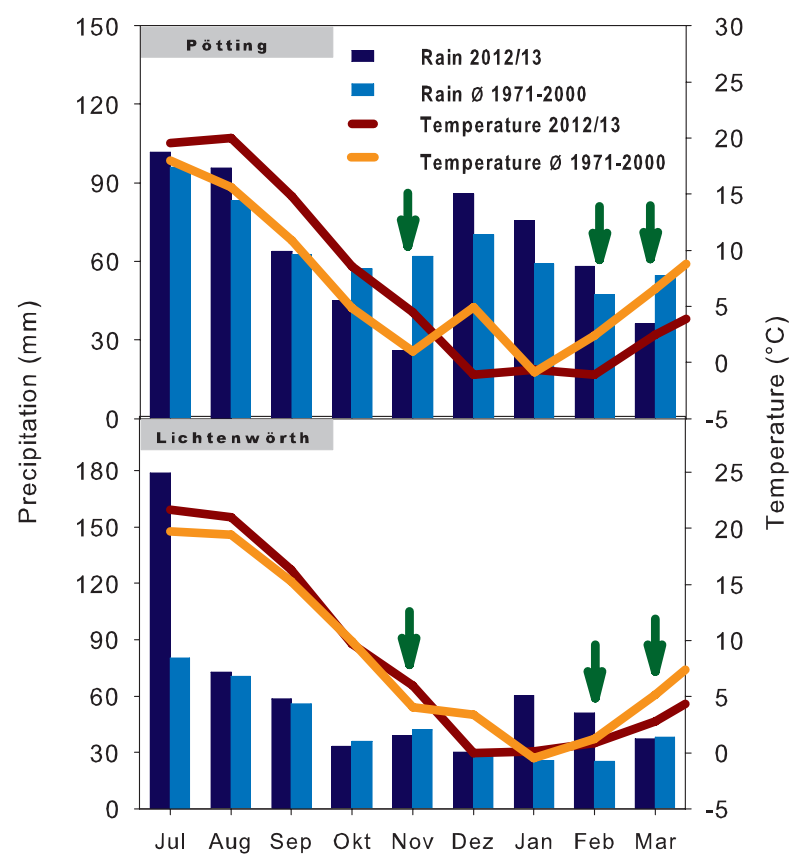

Figure 1. Monthly averages of rainfall and temperature (experimental year and long-term averages) at the two sites. Green arrows indicate the time of greenhouse gas measurements.

Abbildung 1. Monatliche Mittelwerte des Niederschlags und der Temperatur (Versuchsjahr und langjähriges Mittel) auf den beiden Versuchsstandorten. Grüne Pfeile zeigen die Termine der Treibhausgasmessungen. ity. Thus, all data could be treated as spatially independent and tested for treatment effects by analysis of variance. Analysis of variance was performed using a mixed model with measurement dates as repeated measure and an unstructured covariance model for the repeated factor (Piepho et al., 2004).

Another analytical method we applied was joint regression. This technique originates from plant breeding to reveal the distinct response of varieties in different environments (e.g., Annicchiarico, 1997). Environments are characterized via the overall mean of all treatments and are plotted against the single treatments. For this purpose, the two sites were used together thereby defining six "environments" ( 2 sites $\times 3$ measurement dates) from low to high emission potential. Regression analysis was applied to single soil cover emissions versus the average environmental emission potential.

Finally, regression analysis was performed to reveal any causal relations of greenhouse gas emissions versus soil (water content, temperature, $\mathrm{N}$ content, DOC) and plant (C/N ratio, $\mathrm{N}$ concentration) parameters.

All statistical analyses were done using SAS 9.1 with PROC MIXED for analysis of variance and PROC REG for regression analysis. For autocorrelations, the SAS time series viewer was used.

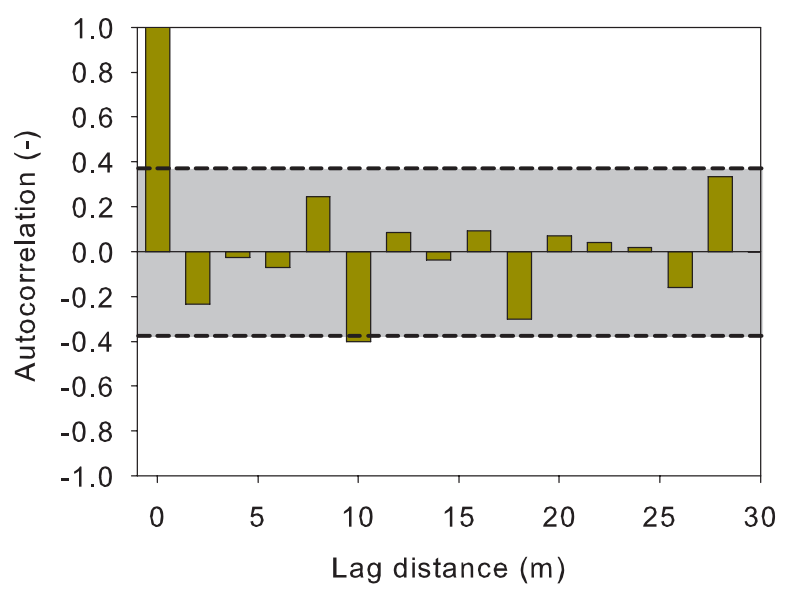

Figure 2. Example of autocorrelation test ( $\mathrm{N}_{2} \mathrm{O}$ Pötting, March 2013). Grey area indicates $95 \%$ confidence band demonstrating that (i) there was no spatial trend and (ii) neighboring samples were generally uncorrelated.

Abbildung 2. Beispiel des Autokorrelationstests $\left(\mathrm{N}_{2} \mathrm{O}\right.$ Pötting, März 2013. Die graue Fläche stellt das $95 \%$-Konfidenzband dar und zeigt, dass (i) keine räumlichen Trends vorliegen und (ii) benachbarte Proben nicht miteinander korrelieren. 
Table 2. Results of mixed model analysis of variance (F-statistics and p-value of main effects and interactions) for greenhouse gas emissions. Significant effects (in case of significant interactions, highest order interaction) are marked in bold.

Tabelle 2. Ergebnis der Varianzanalyse (gemischtes Model; F-Werte und p-Werte der Haupteffekte und ihrer Wechselwirkungen) für Treibhausgasemissionen. Signifikante Effekte (bei signifikanten Interaktionen, die Interaktion höchster Ordnung) sind fett gekennzeichnet.

\begin{tabular}{lcccc}
\hline Effect* & \multicolumn{2}{c}{$\mathrm{N}_{2} \mathbf{O}$} & \multicolumn{2}{c}{$\mathrm{CO}_{2}$} \\
& F-statistic & $\mathrm{p}>\mathrm{F}$ & F-statistic & $\mathrm{p}>\mathrm{F}$ \\
\hline Site & 0.00 & 0.9866 & 6.18 & 0.0180 \\
Date & 6.46 & $\mathbf{0 . 0 0 3 9}$ & 1.58 & 0.2197 \\
Site $\times$ Date & 1.53 & 0.2290 & 9.68 & $\mathbf{0 . 0 0 0 4}$ \\
$\mathrm{N}$ & 0.51 & 0.4785 & 0.00 & 0.9503 \\
Site $\times \mathrm{N}$ & 2.98 & 0.0922 & 1.21 & 0.2782 \\
Date $\times \mathrm{N}$ & 0.00 & 0.9966 & 3.16 & 0.0553 \\
Site $\times$ Date $\times \mathrm{N}$ & 0.05 & 0.9541 & 1.51 & 0.2345 \\
CC & 3.33 & $\mathbf{0 . 0 1 9 5}$ & 9.17 & $<.0001$ \\
Site $\times$ CC & 0.31 & 0.8716 & 0.25 & 0.9090 \\
Date $\times$ CC & 1.81 & 0.0967 & 2.84 & $\mathbf{0 . 0 1 1 3}$ \\
Site $\times$ Date $\times$ CC & 0.4 & 0.9137 & 0.78 & 0.6188 \\
$\mathrm{~N} \times \mathrm{CC}$ & 1.14 & 0.3506 & 1.19 & 0.3325 \\
Site $\times \mathrm{N} \times \mathrm{CC}$ & 0.68 & 0.6070 & 0.19 & 0.9397 \\
Date $\times \mathrm{N} \times \mathrm{CC}$ & 1.50 & 0.1825 & 1.79 & 0.1018 \\
Site $\times$ Date $\times \mathrm{N} \times \mathrm{CC}$ & 0.66 & 0.7226 & 0.16 & 0.9954 \\
Rep & 0.29 & 0.7510 & 0.73 & 0.4877 \\
Date $\times$ Rep & 1.18 & 0.3311 & 0.88 & 0.4856 \\
\hline * & & & &
\end{tabular}

*Site refers to experimental location, date to measurement date, $\mathrm{N}$ is $\mathrm{N}$ fertilization treatment, CC is soil cover treatment, Rep is replication.

\section{Results}

\subsection{Cover crop biomass and $\mathrm{C} / \mathrm{N}$ ratio}

Figure 3 shows the cover crop dry matter and $\mathrm{C} / \mathrm{N}$ ratio at the two sites. There was a significant interaction between site and cover crop species for dry matter, while $\mathrm{C} / \mathrm{N}$ ratio showed only significant site and species main effects.

Cover crops achieved a relatively high dry matter yield at both sites compared to literature values (e.g., Lütke Entrup, 2000). Mustard and cress-mungo-radish mixture had higher dry matter yield at Lichtenwörth compared to the mixtures of mustard-phacelia and Alexandrian cloverMungo-phacelia. At Pötting, on the contrary, mustard had the lowest dry matter yield, while all the other cover crops were at a similar level. This was obviously related to the later sowing date of mustard. Dry matter yield of both mustard and cress-mungo-radish mixture differed significantly between sites.
$\mathrm{C} / \mathrm{N}$ ratio was lowest for mustard and highest for the mustard-phacelia mixture. The legume containing mixture (Alexandrian clover-Mungo-phacelia) was between these two variants. In average, the sub-humid site showed a significantly higher $\mathrm{C} / \mathrm{N}$ ratio of biomass compared to the humid site.

\subsection{Greenhouse gas emissions}

Figure 4 shows the boxplots of the measured $\mathrm{N}_{2} \mathrm{O}$ and $\mathrm{CO}_{2}$ emissions. It reveals the average emission potential for each date and site as well as the high variability of soil emissions that has been described in several studies (e.g., Partkin, 1987; Rochette et al., 1991).

$\mathrm{N}_{2} \mathrm{O}$ emissions were generally low. The median of values was near zero in all cases. The highest $\mathrm{N}_{2} \mathrm{O}$ flux at Pötting was registered in March 2013 with a mean value of $6.3 \mu \mathrm{g}$ $\mathrm{m}^{-2} \mathrm{~h}^{-1}$ and a peak of $31.4 \mu \mathrm{g} \mathrm{m}^{-2} \mathrm{~h}^{-1}$. At Lichtenwörth, the highest emissions were measured in February 2013 with a mean of $5.4 \mu \mathrm{g} \mathrm{m}^{-2} \mathrm{~h}^{-1}$ and a maximum of $46.6 \mu \mathrm{g} \mathrm{m}^{-2} \mathrm{~h}^{-1}$. Average $\mathrm{CO}_{2}$ emissions were higher at Pötting $(15.1 \mathrm{mg}$ $\left.\mathrm{m}^{-2} \mathrm{~h}^{-1}\right)$ compared to Lichtenwörth $\left(7.9 \mathrm{mg} \mathrm{m}^{-2} \mathrm{~h}^{-1}\right)$. At Pötting, the measurement date showed stronger influence on the average $\mathrm{CO}_{2}$ flux with a clear depression in February 2012. At Lichtenwörth, on the contrary, the variation between the measurement dates was low $\left( \pm 1.3 \mathrm{mg} \mathrm{m}^{-2} \mathrm{~h}^{-1}\right)$. Table 2 shows the ANOVA results for the influence of main and interaction effects on the measured greenhouse gas emissions.

$\mathrm{N}_{2} \mathrm{O}$ emissions differed significantly between measurement dates and cover crop species. Interestingly, there was no significant difference between the average $\mathrm{N}_{2} \mathrm{O}$ emissions at the two sites. $\mathrm{CO}_{2}$ emissions showed significant interactions of date with site and cover crop species. Species effects $\left(\mathrm{N}_{2} \mathrm{O}\right.$ main effect, $\mathrm{CO}_{2}$ date $\times$ species interaction $)$ are shown in Figure 5.

The species effect for $\mathrm{N}_{2} \mathrm{O}$ emissions clearly indicated that monocropping a brassica species resulted in significantly higher nitrous oxide losses compared to the other treatments, which did not differ significantly among each other. Concerning measurement dates (cf. Figure 4), the first measurement in November $\left(0.9 \mu \mathrm{g} \mathrm{m}^{-2} \mathrm{~h}^{-1}\right)$ at the end of cover crop growth was significantly lower as compared to the measurements in February $\left(3.7 \mu \mathrm{g} \mathrm{m}^{-2} \mathrm{~h}^{-1}\right)$ and March $\left(4.3 \mu \mathrm{g} \mathrm{m}^{-2} \mathrm{~h}^{-1}\right)$ that did not differ among each other.

Species effects for $\mathrm{CO}_{2}$ (Figure $5 \mathrm{~b}$ ) revealed the highest emissions for the cover cropped plots at the first measurement date. Mixtures of mustard-phacelia and cress-mun- 


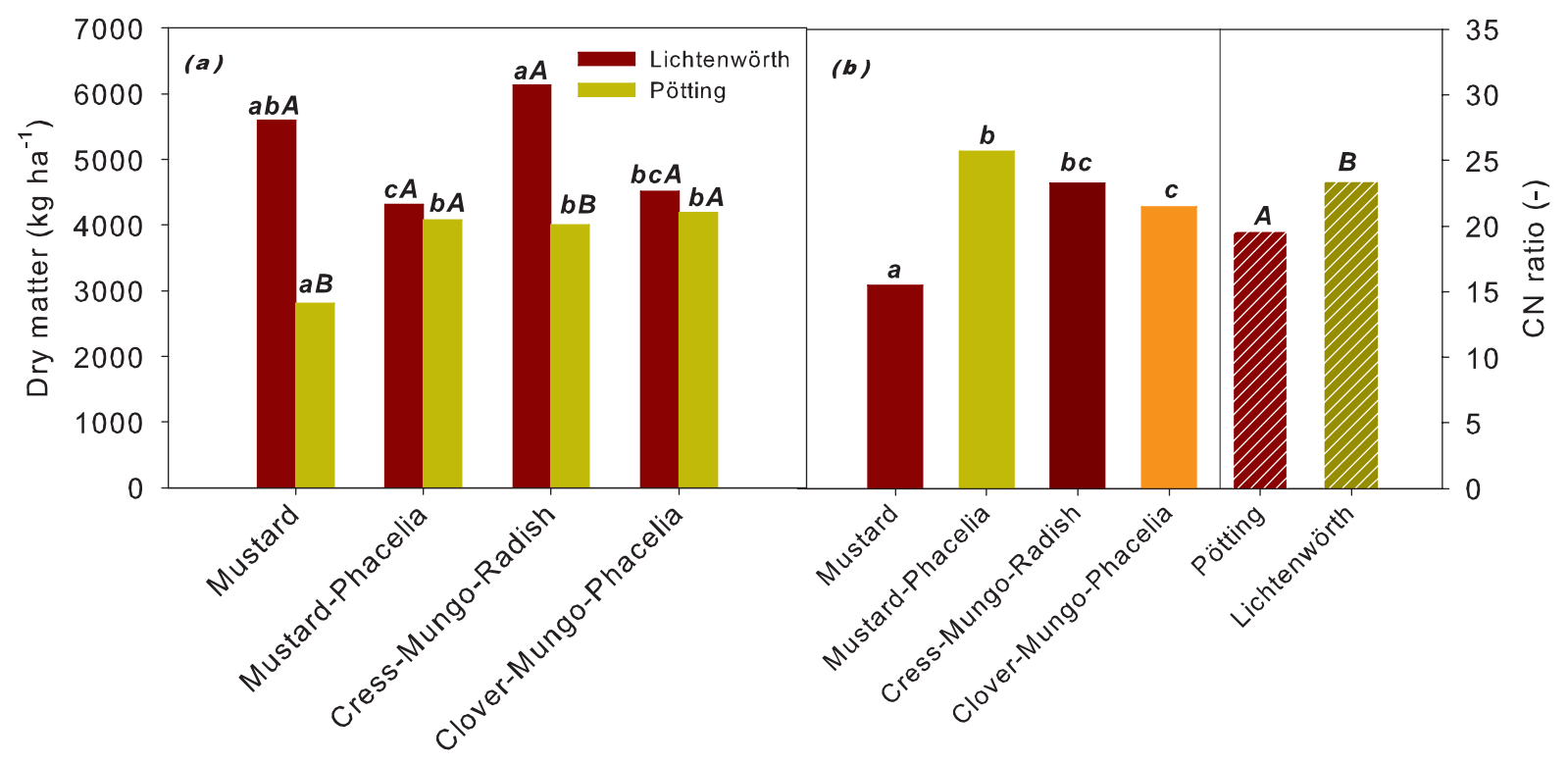

Figure 3. Cover crop dry matter and $\mathrm{C} / \mathrm{N}$ ratio at the two experimental sites. Significant differences for $\mathrm{p}<0.05$ between sites are indicated by upper-case letters, while differences between cover crop species at one site (dry matter) and average species differences $(\mathrm{C} / \mathrm{N}$ ratio) are indicated by lower-case letters.

Abbildung 3. Zwischenfrucht-Trockenmasse und C/N-Verhältnis auf den beiden Versuchsstandorten. Signifikante Unterschiede (p < 0,05) zwischen den Standorten sind mit Großbuchstaben gekennzeichnet, während Unterschiede zwischen den Arten innerhalb eines Standortes (Trockenmasse) und mittlere Artenunterschiede (C/N-Verhältnis) mit Kleinbuchstaben gezeigt werden.

go-radish showed a significant increase of $\mathrm{CO}_{2}$ losses in March, following the lowest emissions in February. Fallow had no significant differences between dates, while mustard and clover-mungo-phacelia were at a similar level in February and March. On average, all the cover cropped plots had significantly higher $\mathrm{CO}_{2}$ emissions compared to the fallow in November and February. In March, the $\mathrm{CO}_{2}$ flux was similar for all treatments except the mustardphacelia mixture that had a significantly higher value.

The date $\times$ site interaction for $\mathrm{CO}_{2}$ emissions can be inferred from Figure 4. Sites differed significantly in Novem- ber (Pötting $20.8 \mathrm{mg} \mathrm{m}^{-2} \mathrm{~h}^{-1}$, Lichtenwörth $7.0 \mathrm{mg} \mathrm{m}^{-2}$ $\mathrm{h}^{-1}$ ), while being similar in February $\left(7.6\right.$ and $9.2 \mathrm{mg} \mathrm{m}^{-2}$ $\mathrm{h}^{-1}$ ) and March (16.9 and 7.4 $\left.\mathrm{mg} \mathrm{m}^{-2} \mathrm{~h}^{-1}\right)$. At Pötting, the emissions in February were significantly lower compared to November and March; while at Lichtenwörth, the $\mathrm{CO}_{2}$ emissions were at a similar level at all measurement dates. In March, the variability of $\mathrm{CO}_{2}$ values in Pötting was particularly high.

It can be hypothesized that the treatment differences become more evident when the average emission potential is high. Figure 6 compares the increase of single treatment

Table 3. Regression relations between soil chemical and physical parameters and greenhouse gas emissions

Tabelle 3. Regressionsbeziehungen bodenchemischer und bodenphysikalischer Parameter mit Treibhausgasemissionen

\begin{tabular}{lllll}
\hline Site & Factors & Equation & $\mathbf{R}^{2}$ & p-value \\
\hline Pötting & Soil mineral $\mathrm{N}_{\text {vs }} \mathrm{CO}_{2}$ & $\mathrm{y}=-4.36+0.57 \mathrm{x}$ & 0.32 & 0.028 \\
& DOC vs $\mathrm{N}_{2} \mathrm{O}$ & $\mathrm{y}=-8.82+0.37 \mathrm{x}$ & 0.41 & 0.046 \\
& Soil water content vs. $\mathrm{N}_{2} \mathrm{O}$ & $\mathrm{y}=-16.56+0.52 \mathrm{x}$ & 0.39 & 0.013 \\
\multirow{2}{*}{ Lichtenwörth } & DOC vs. $\mathrm{N}_{2} \mathrm{O}$ & $\mathrm{y}=-5.21+0.26 \mathrm{x}$ & 0.58 & 0.011 \\
& Soil water content vs. $\mathrm{CO}_{2}$ & $\mathrm{y}=-14.11+0.83 \mathrm{x}$ & 0.41 & 0.56 \\
& Soil water content vs. $\mathrm{N}_{2} \mathrm{O}$ & $\mathrm{y}=-24.63+1.04 \mathrm{x}$ & 0.001 & 0.56 \\
\hline
\end{tabular}




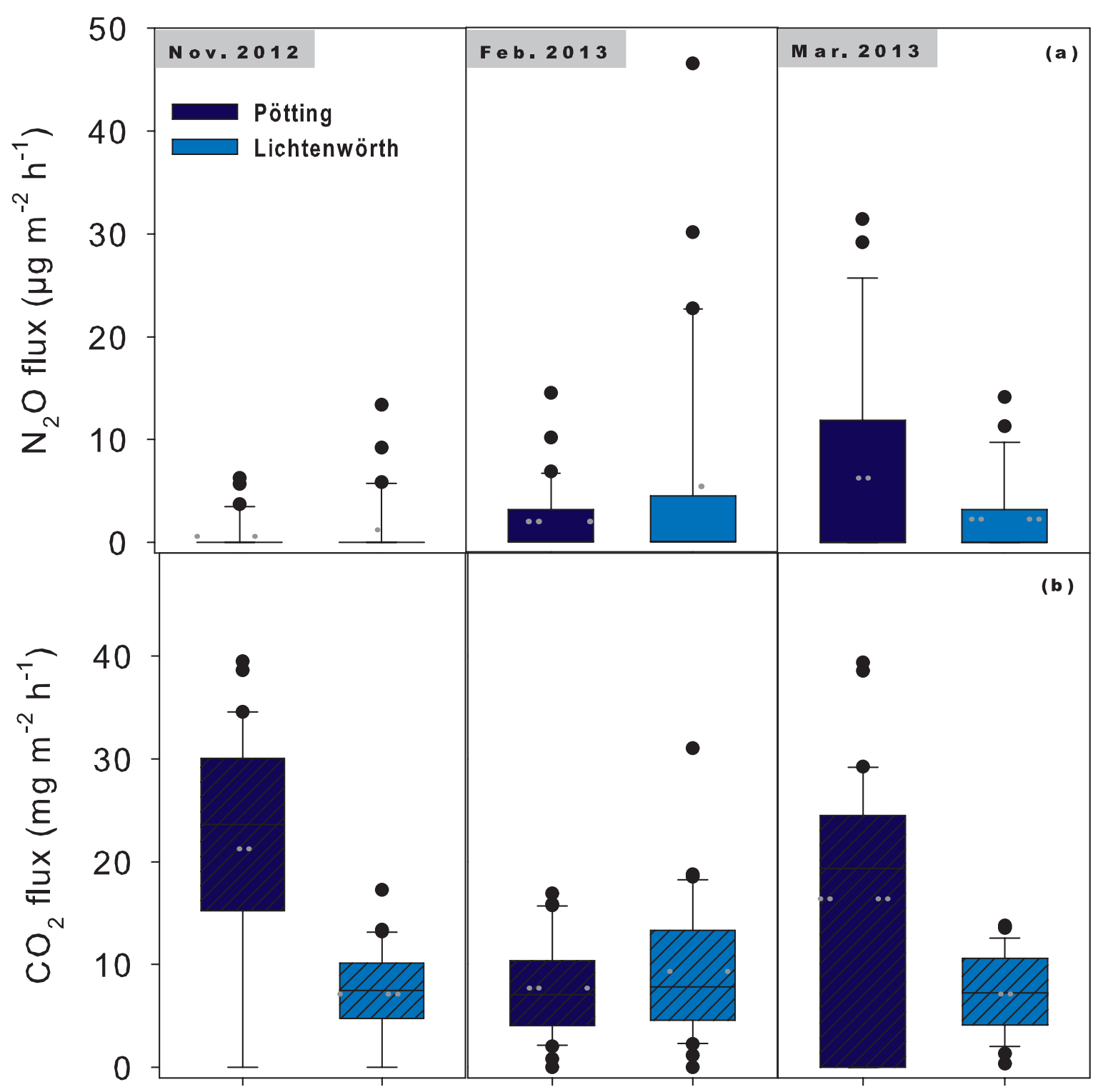

Figure 4. Boxplots of (a) $\mathrm{N}_{2} \mathrm{O}$ and (b) $\mathrm{CO}_{2}$ emissions from soil at the two measurement sites. Dark blue boxes are for the humid site (Pötting, OÖ), while light blue boxes are for the sub-humid site (Lichtenwörth, NÖ). Dotted lines show the mean values.

Abbildung 4. Boxplots der (a) $\mathrm{N}_{2} \mathrm{O}$ und (b) $\mathrm{CO}_{2}$-Emissionen des Bodens an den beiden Versuchsstandorten. Dunkelblaue Boxen stehen für den Standort im Feuchtgenbiet (Pötting, OÖ), hellblaue Boxen für den subhumiden Standort (Lichtenwörth, NÖ). Strichlierte Linien zeigen den Mittelwert.

emissions with increasing environmental emission potential (joint regression). For $\mathrm{N}_{2} \mathrm{O}$, the application of organic $\mathrm{N}$ fertilizer resulted in higher emission over the whole range of emission levels. For $\mathrm{CO}_{2}$ emissions, no differences in average level and trend could be found between the $\mathrm{N}$-treatments. Comparing the soil cover treatments, there was a clear difference of mustard that leads to substantially higher emissions compared to the other treatments in high emission environments. For the other treatments, confidence bands were overlapping over the whole range of emission levels.
In case of $\mathrm{CO}_{2}$ emissions, joint regression did not reveal a clear distinction among the treatments. Still, it is evident that fallow has the lowest $\mathrm{CO}_{2}$ emission and differentiation to the cover cropped soil tends to increase with increasing emission potential.

\subsection{Causal factors for greenhouse gas emissions}

In order to understand the role of causal factors for greenhouse gases formation, we determined regression relations 


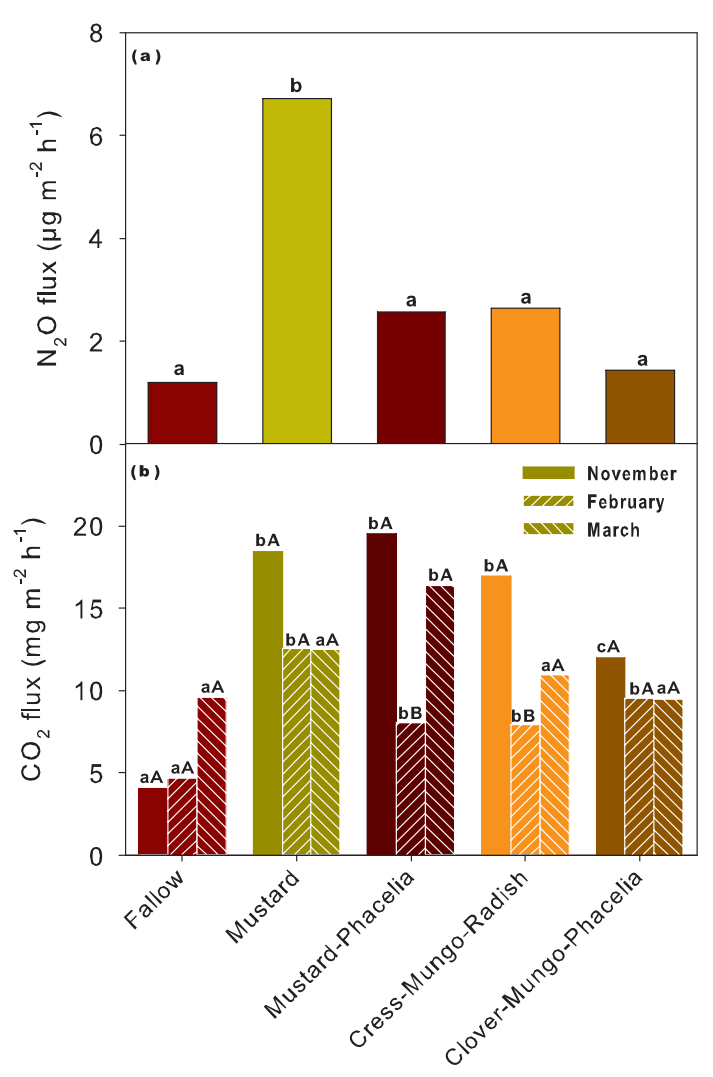

Figure 5. Greenhouse gas emissions $\left(\mathrm{N}_{2} \mathrm{O}\right.$ and $\left.\mathrm{CO}_{2}\right)$ from different cover crop treatments and fallow. Significant species differences for $\mathrm{N}_{2} \mathrm{O}$ (Fig. 5a) are indicated by lower-case letters. For $\mathrm{CO}_{2}$ (Fig. 5b) lowercase letters refer to species differences at the same measurement date, while upper-case letters indicate differences between dates for a given species. Variants sharing a common letter do not differ significantly at $\mathrm{p}<0.05$.

Abbildung 5. Treibhausgasemissionen $\left(\mathrm{N}_{2} \mathrm{O}\right.$ und $\left.\mathrm{CO}_{2}\right)$ von unterschiedlichen Zwischenfrüchten und Schwarzbrache. Signifikante Artunterschiede für $\mathrm{N}_{2} \mathrm{O}$ (Abb. 5a) sind mit Kleinbuchstaben gekennzeichnet. Für $\mathrm{CO}_{2}$ (Abb. 5b) zeigen Kleinbuchstaben Artunterschiede beim selben Messtermin, während Großbuchstaben die Unterschiede zwischen den Messterminen für eine Art zeigen. Varianten mit gleichem Buchstaben unterscheiden sich nicht signifikant bei $p<0,05$.

of $\mathrm{CO}_{2}$ and $\mathrm{N}_{2} \mathrm{O}$ with soil chemical (mineral N, DOC; Figure 7) and soil physical (water content, temperature; Figure 8) parameters. For significant relations, regression equations, $\mathrm{R}^{2}$ and significance levels are given in Table 3. Among the soil chemical factors, a slight significant relation was found between $\mathrm{CO}_{2}$ and soil mineral $\mathrm{N}$ at Lichtenwörth. At both sites, the $\mathrm{N}_{2} \mathrm{O}$ emissions were not influenced by soil mineral N. DOC and soil water content were found as a significant causal factor for $\mathrm{N}_{2} \mathrm{O}$ emissions at both sites. At the semi-arid site Lichtenwörth, increasing soil water content also resulted in higher $\mathrm{CO}_{2}$ emissions.
Soil temperature influenced neither $\mathrm{CO}_{2}$ nor $\mathrm{N}_{2} \mathrm{O}$ emissions under the given temperature ranges during the cover crop period.

Finally, we tested if either cover crop biomass or quality of residues $(\mathrm{C} / \mathrm{N}, \mathrm{N})$ were directly related to any of the two greenhouse gasses. For this purpose, we pooled together the cover crop data from both sites resulting in 8 data pairs ( 4 cover crops $\times 2$ sites). A significant relation was found between the $\mathrm{N}$ content of biomass and $\mathrm{N}_{2} \mathrm{O}$ emissions in February (Figure 9; $\mathrm{R}^{2}=0.50, \mathrm{p}=0.05$ ). Although significant, the regression has to be interpreted with care due to the clustering of observations at two extremes with the high $\mathrm{C} / \mathrm{N}$ ratio mustard variants at the upper end and the other species with similar $\mathrm{C} / \mathrm{N}$ values at the lower end.

\section{Discussion}

This study reports greenhouse gas emissions $\left(\mathrm{CO}_{2}, \mathrm{~N}_{2} \mathrm{O}\right)$ from cover cropped compared to fallow soil. Cover cropping is considered a potential measure to mitigate $\mathrm{N}_{2} \mathrm{O}$ emissions from agricultural soils mainly due to the reduction of soil $\mathrm{NO}_{3}$ content (McSwiney et al., 2010). Furthermore, it is suggested as a measure for carbon sequestration in agricultural soil (Lal, 2011). On the other hand, addition of easily mineralizable carbon from cover crop residues might also stimulate greenhouse gas formation (Mitchell et al., 2013). Under Central European climatic conditions, hot moments for $\mathrm{N}_{2} \mathrm{O}$ emissions can be expected between the period of cover crop termination by frost in late autumn (residue addition to the soil) and the start of the subsequent main crop in spring, for example, the periods of snow melting, freezing-thawing and high levels of water filled porosity (Hagedorn et al., 2011).

\subsection{Emission potential following cover crops}

Our results demonstrated that even during hot moments of $\mathrm{N}_{2} \mathrm{O}$ emissions between late autumn and early spring, average fluxes were low. For better comparison, Figure 10 provides a time series of the subsequent emissions between March and end of June 2013 at the humid (high emission) site for three soil cover treatments (fallow, mustard, non-brassica mixture of clover-mungo-phacelia). This period included $\mathrm{N}$-fertilization (pig slurry + urea; $162 \mathrm{~kg} \mathrm{~N} \mathrm{ha}^{-1}$ ), tillage (ploughing) and sowing of the main crop (maize). 


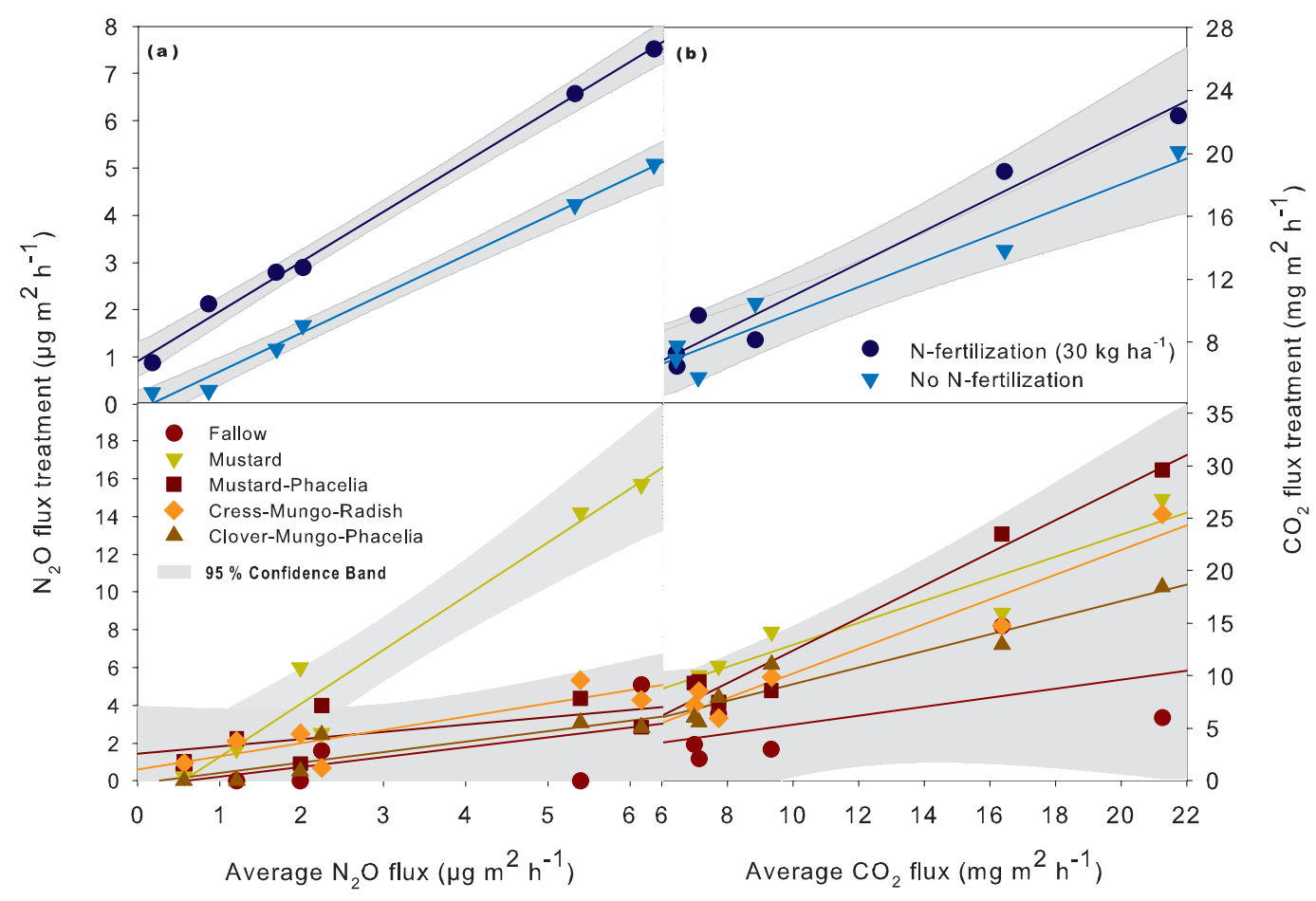

Figure 6. Trend of single treatment emissions at increasing the average emission potential (joint regression) for (a) $\mathrm{N}_{2} \mathrm{O}$ and (b) $\mathrm{CO}_{2}$. The upper part of the figure shows the influence of $\mathrm{N}$-fertilization while the lower part shows the different cover crops and fallow. Grey shaded areas represent $95 \%$ confidence bands.

Abbildung 6. Trend der Emission der einzelnen Behandlungen bei steigendem Emissionspotential (Joint Regression) für (a) $\mathrm{N}_{2} \mathrm{O}$ und (b) $\mathrm{CO}_{2}$. Der obere Teil der Abbildung zeigt den Einfluss der N-Düngung, während der untere Teil die unterschiedlichen Zwischenfrüchte und Schwarzbrache zeigt. Die graue Fläche repräsentiert das $95 \%$-Konfidenzband.

Comparing Figure $4 \mathrm{a}$ and $10 \mathrm{a}$, it is obvious that the main $\mathrm{N}_{2} \mathrm{O}$ losses are related to operations during the main crop, particularly tillage and $\mathrm{N}$-fertilization. Here, an $\mathrm{N}_{2} \mathrm{O}$ peak as high as $2316 \mu \mathrm{g} \mathrm{m}^{-2} \mathrm{~h}^{-1}$ ( $\mathrm{N}$-application + tillage, $87.6 \%$ water filled porosity, $23.0^{\circ} \mathrm{C}$ soil temperature) occurred. A second peak of $874.4 \mathrm{~g} \mathrm{~m}^{-2} \mathrm{~h}^{-1}$ was measured on $2^{\text {nd }}$ June following an intense rainfall with soil at $80.4 \%$ of water filled porosity, soil temperature of $11.5^{\circ} \mathrm{C}$ and mineral $\mathrm{N}$ in the topsoil $(0-5 \mathrm{~cm})$ of $36.7 \mathrm{~kg} \mathrm{ha}^{-1}$. On the contrary, the highest emission to be considered an immediate spillover effect of cover cropping at this site was $31.5 \mu \mathrm{g} \mathrm{m}^{-2} \mathrm{~h}^{-1}$ in a mustard plot in March 2013. This is in agreement with Petersen et al. (2011) who also reported $\mathrm{N}_{2} \mathrm{O}$ values near zero during the cover crop period, while values increased to $900 \mu \mathrm{g} \mathrm{m}^{-2} \mathrm{~h}^{-1}$ until May in the subsequent vegetation period. Several studies reported high $\mathrm{N}_{2} \mathrm{O}$ fluxes following $\mathrm{N}$-fertilization (e.g., Arcara et al., 1999) and rainfall events saturating the topsoil (e.g., Jacinthe and Dick, 1997). Dobbie and Smith (2001) showed that a temperature increase between 5 and $12^{\circ} \mathrm{C}$ strongly stimulated $\mathrm{N}_{2} \mathrm{O}$ emissions, while the temperature effect became lower when further increasing soil temperature from 12 to $18^{\circ} \mathrm{C}$. Thus, soil temperatures at soil thawing (February) and snow melting (March) were probably still suboptimum for microbial activity catalyzing denitrification. Furthermore, soil mineral $\mathrm{N}$ levels in the top soil in February (Pötting: $26.7 \mathrm{~kg} \mathrm{ha}^{-1}$; Lichtenwörth: $26.1 \mathrm{~kg} \mathrm{ha}^{-1}$ ) and March (Pötting: $34.4 \mathrm{~kg}$ ha $^{-1}$; Lichtenwörth: $37.8 \mathrm{~kg} \mathrm{ha}^{-1}$ ) were substantially lower compared to the values registered during the main cropping period (up to $179 \mathrm{~kg} \mathrm{~N} \mathrm{ha}^{-1}$ ). From this comparison, it can be concluded that $\mathrm{N}_{2} \mathrm{O}$ emissions following cover crops are negligible compared to emissions during the main cropping period mainly due to environmental constraints (low soil temperature and $\mathrm{N}$-content). We also notice here that $\mathrm{N}_{2} \mathrm{O}$ emissions from April onwards (cf. Figure 10a) did not show a distinctive trend between the cover cropped and fallowed plots, which is in agreement with other studies (e.g., Parkin and Kaspar, 2006). 


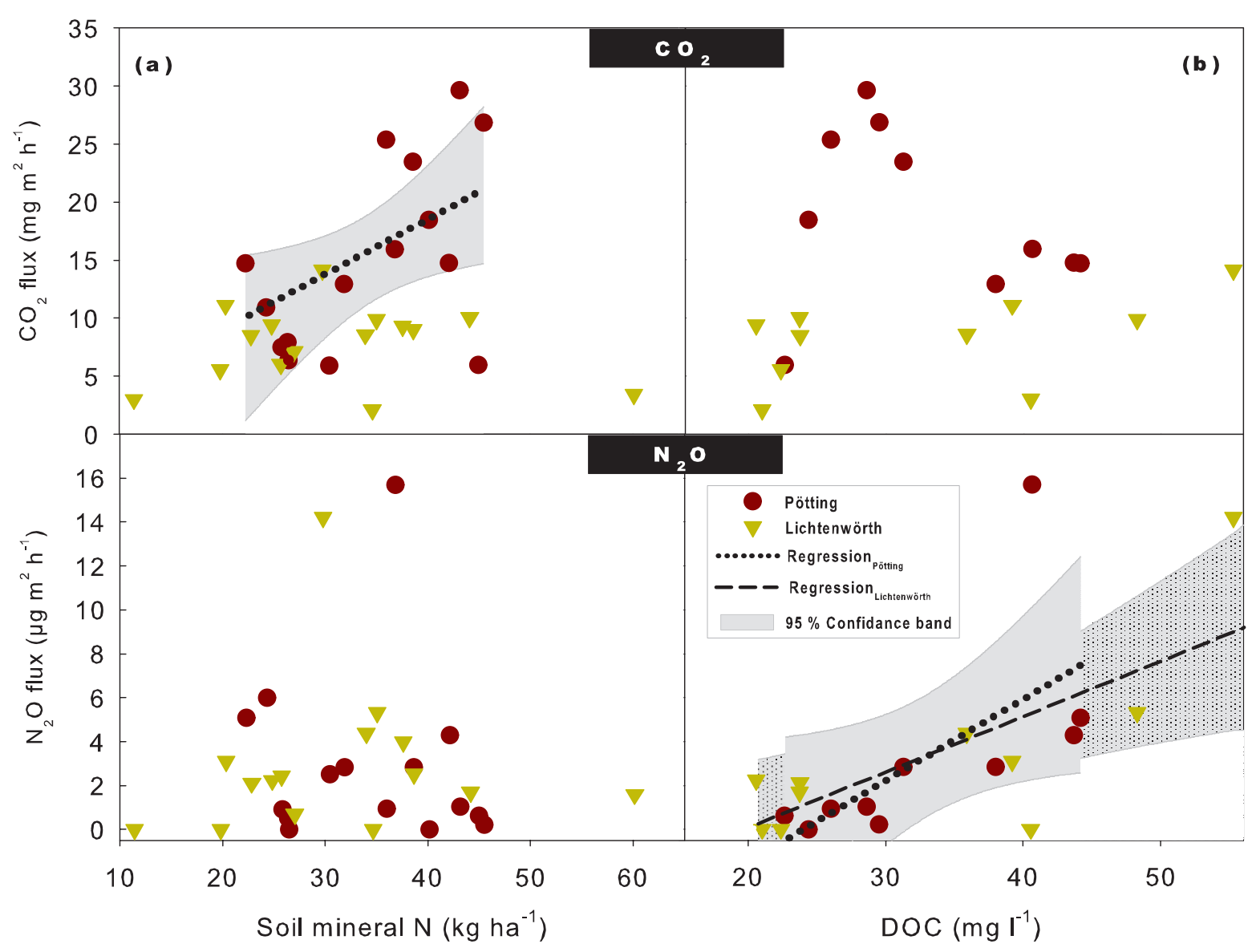

Figure 7. Relation between (a) soil mineral N, and (b) dissolved organic carbon (DOC) with $\mathrm{CO}_{2}$ and $\mathrm{N}_{2} \mathrm{O}$ emissions. In case of significant regressions, regression lines (Pötting: dotted line; Lichtenwörth: medium dashed line) and confidence bands (Pötting: grey area; Lichtenwörth: grey squared area).

Abbildung 7. Beziehung zwischen (a) mineralischen N-Gehalt des Bodens und (b) gelöstem organischen Kohlenstoff (DOC) mit den Emissionen von $\mathrm{CO}_{2}$ und $\mathrm{N}_{2} \mathrm{O}$. Für signifikante Regressionen sind die Regressionsgeraden (Pötting: gepunktete Linie; Lichtenwörth: strichlierte Linie) und das Konfidenzband gegeben (Pötting: graue Fläche; Lichtenwörth: grau schattierte Fläche).

Differences in the height of $\mathrm{CO}_{2}$ flux between the period from late autumn to early spring and the subsequent period until early summer were less pronounced compared to $\mathrm{N}_{2} \mathrm{O}$. This shows the substantially stronger response of $\mathrm{N}_{2} \mathrm{O}$ to hot spots and hot moments compared to $\mathrm{CO}_{2}$ leading to higher spatial and temporal variability (Parkin, 1987; Yao et al., 2010). Following frost termination of cover crops, the highest average $\mathrm{CO}_{2}$ emissions were measured in November upon fresh residue addition to the soil $\left(21.3 \mathrm{mg} \mathrm{m}^{-2} \mathrm{~h}^{-1}\right)$, while the highest average value during the main crop time series was $52.7 \mathrm{mg} \mathrm{m}^{-2} \mathrm{~h}^{-1}$ on $16^{\text {th }}$ June 2013. A first peak of $\mathrm{CO}_{2}$ was coincident with the $\mathrm{N}_{2} \mathrm{O}$ peak (5 $5^{\text {th }}$ May 2013) following tillage and $\mathrm{N}$-fertilization. In this case, the emis- sions from fallow were significantly lower, which indicates an $\mathrm{N}$-fertilizer induced mineralization push of cover crop residues. The second emission peak for $\mathrm{CO}_{2}$ on $16^{\text {th }}$ June was registered two weeks later compared to $\mathrm{N}_{2} \mathrm{O}$, coincident with very high soil temperature $\left(26.9^{\circ} \mathrm{C}\right)$ and lower water content (18.4\%). Generally, the main driver of $\mathrm{CO}_{2}$ emissions $\left(R^{2}=0.63 ; p<0.001\right)$ was soil temperature.

\subsection{Effect of different over-winter soil coverage on greenhouse gas emissions}

Cover cropping is expected to reduce nitrous oxide emissions via plant uptake of soil mineral $\mathrm{N}$ as well as micro- 
bial $\mathrm{N}$-immobilization during residue decomposition. Most studies comparing different cover crop treatments focused on legumes versus non-legumes assuming that the latter contribute more to mitigation of greenhouse gas emissions due to higher depletion of soil $\mathrm{NO}_{3}{ }^{-}$and lower residue $\mathrm{C} / \mathrm{N}$ ratio (e.g., Rosecrance et al., 2000; Baggs et al., 2000; Flessa et al., 2002; Basche and Miguez, 2012; Sanz-Cobena et al., 2014). However, availability of easily decomposable $\mathrm{C}$ from cover crop residues can also cause higher emissions (Mitchell et al., 2013). Concerning $\mathrm{CO}_{2}$, Lal (2011) attributes cover crops a potential to sequester $\mathrm{C}$ in agricultural soil. Still most cover crop residues are allocated to the easily degradable soil $\mathrm{C}$ pool and are readily mineralized (Puget and Drinkwater, 2001).

Cover crop treatments in our experiment were mainly species mixtures except for mustard as a predominant species in Central Europe. Mixtures combine single species environmental benefits and increase biodiversity within the main crop monocultures (e.g., Creamer et al., 1997; Snapp et al., 2005). Our results clearly showed a distinctive behavior of mustard with a significant increase of $\mathrm{N}_{2} \mathrm{O}$ emissions during the high emission moments between late autumn and early spring. In the subsequent main crop vegetation period, there was no evidence of enhanced emissions from mustard plots (cf. Figure 10). In a study of Baggs et al. (2000) in Scotland, on the contrary, no enhanced emissions from mustard were registered. In this study, the $\mathrm{N}_{2} \mathrm{O}$ measurements were performed after cover crop incorporation in April. The authors reported comparatively dry soil conditions and attributed $\mathrm{N}_{2} \mathrm{O}$ formation to nitrification. Furthermore, mustard residues in their experiment had larger C/N ratio (30.3:1) compared to our study (15.5:1). Petersen et al. (2011) found slightly higher emissions after freezing-thawing events from plots with fodder radish compared to fallow, which they attributed to residue mineralization and higher soil $\mathrm{NO}_{3}$ contents during warmer periods over winter. Similar to our study, the general emission level before the main crop vegetation period was low. Velthof et al. (2002) also reported peak $\mathrm{N}_{2} \mathrm{O}$ losses for brassica species (broccoli, mustard, white cabbage, Brussels sprouts) compared to cereals and sugar beet leaf. They related these differences mainly to distinct $\mathrm{C} / \mathrm{N}$ ratio and water-soluble $\mathrm{N}$ content of residues. Interestingly, sugar beet leaf with similarly low $\mathrm{C} / \mathrm{N}$ ratio still had low $\mathrm{N}_{2} \mathrm{O}$ emissions. Velthof et al. (2002) indicated a $\mathrm{C} / \mathrm{N}$ ratio $<30$ as a threshold for enhanced denitrification losses. In our case, all residues had $\mathrm{C} / \mathrm{N}$ ratios $<26: 1$ with lowest value for mustard. The clearly distinctive behavior of mustard suggests that also biomass quality, that is, glucosinolates in brassica species, had further enhanced $\mathrm{N}_{2} \mathrm{O}$ losses when all other conditions (low $\mathrm{C} / \mathrm{N}$ ratio, high water filled pore space) are conducive to nitrous oxide formation. Glucosinolate content is about 1\% of fresh weight, with biochemistry and concentration varying between plant organs and with plant age (Fahey et al., 2001). During decomposition of the mustard glucosinolate sinigrin, allyl-isothiocyanate and $\mathrm{SO}_{4}^{2-}$ are formed. Production of glucose, subject to fermentation under anaerobic conditions, further lowers the soil oxygen content. In this process, $\mathrm{H}_{2} \mathrm{~S}$ is formed, decreasing the soil redox potential and acting as a bactericide, thereby providing additional substrate for anaerobic decomposition (Fahey et al., 2001; Mentler, 2015, personal communication). Thus, several aspects in this process (oxygen consumption, lowering of $\mathrm{rH}$, and addition of easily decomposable substrate) drives denitrification beyond the level found for other residues under similar environmental conditions. Mixtures including brassica species however did not show enhanced emissions. This is probably explained by either their lower seeding density within mixtures or differences in plant senescence.

$\mathrm{CO}_{2}$ emissions were readily increased by cover crops upon frost killing in late autumn and thereafter decreased until spring. Also, Magid et al. (2004) demonstrated quick release of $\mathrm{N}$ and $\mathrm{C}$ from the cover crop residues after incorporation even at low temperatures $\left(3^{\circ} \mathrm{C}\right)$. Taking the bare soil treatment as reference for $\mathrm{CO}_{2}$ respiration, $\mathrm{CO}_{2}$ release from the cover cropped plots was $313.7 \%, 103.1 \%$ and $28.7 \%$ above fallow in November, February and March respectively. Mixtures of mustard-phacelia and cress-mungo-radish had a significant depression of $\mathrm{CO}_{2}$ fluxes in February before the onset of spring mineralization. Their wider $\mathrm{C} / \mathrm{N}$-ratio probably slowed down the decomposition process to a larger extent under lower soil temperatures and microbial activity in February. We notice here that $\mathrm{CO}_{2}$ emissions from cover cropped plots do not allow inferring on potential soil carbon storage from the added plant material. Lal et al. (1998) estimated carbon sequestration from cover crops between 100-300 kg C ha ${ }^{-1} \mathrm{yr}^{-1}$ depending on residue quality (Puget and Drinkwater, 2001) and interaction with soil aggregation (Kong et al., 2005). Concerning fallow, the measured $\mathrm{CO}_{2}$ emissions in any case are losses from the soil organic carbon pool, which are not counterbalanced by any previous inputs.

\subsection{Environmental and crop factors driving gaseous losses}

The conflicting results on cover crop induced $\mathrm{N}_{2} \mathrm{O}$ emissions are explained by their different impact on either of 


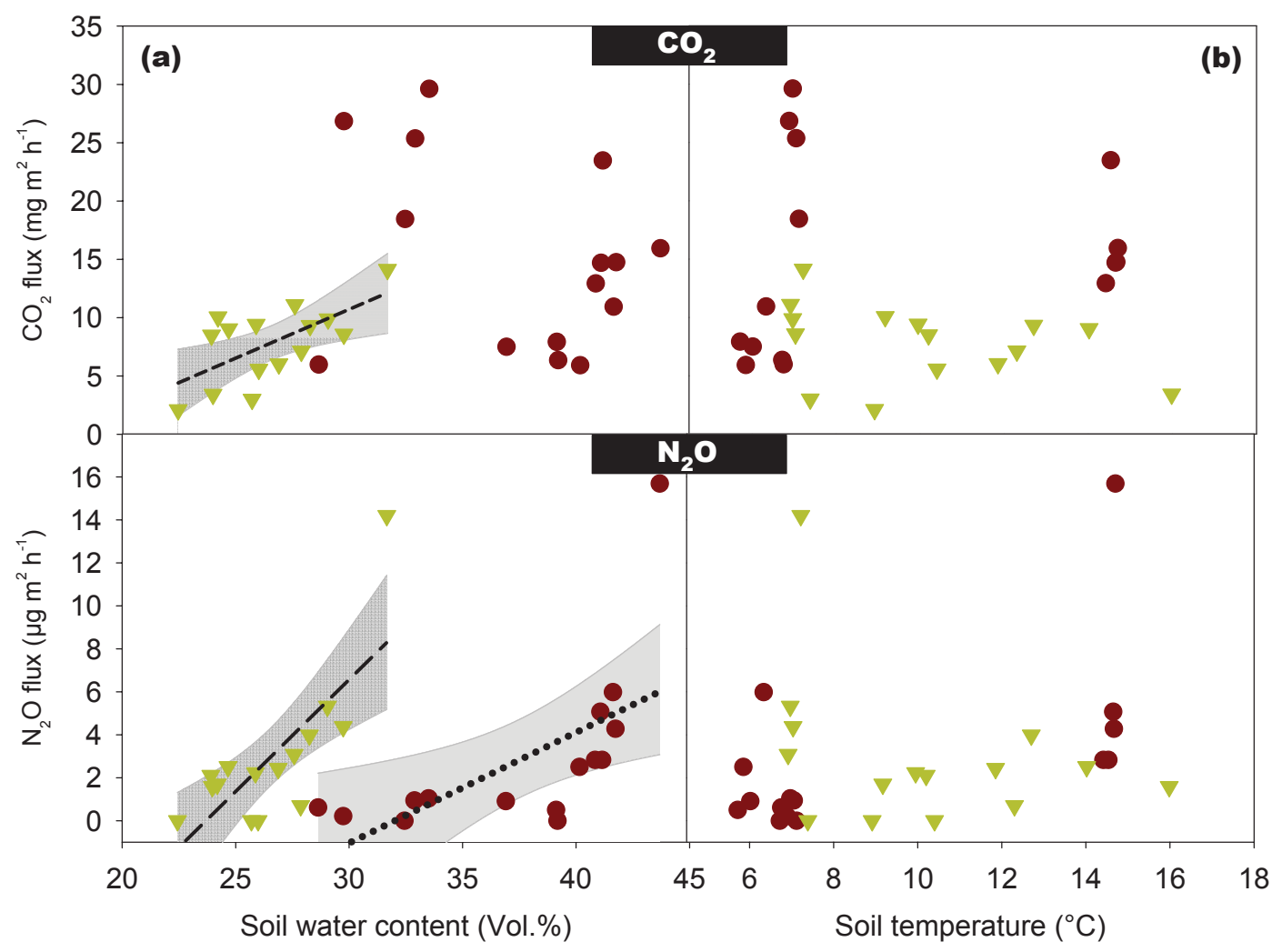

Figure 8. Relation between (a) soil water content, and (b) soil temperature with $\mathrm{CO}_{2}$ and $\mathrm{N}_{2} \mathrm{O}$ emissions. In case of significant regressions, regression lines (Pötting: dotted line; Lichtenwörth: medium dashed line) and confidence bands (Pötting: grey area; Lichtenwörth: grey squared area).

Abbildung 8. Beziehung zwischen (a) Bodenwassergehalt und (b) Bodentemperatur mit den Emissionen von $\mathrm{CO}_{2}$ und $\mathrm{N}_{2} \mathrm{O}$. Für signifikante Regressionen sind die Regressionsgeraden (Pötting: gepunktete Linie; Lichtenwörth: strichlierte Linie) und das Konfidenzband gegeben (Pötting: graue Fläche; Lichtenwörth: grau schattierte Fläche).

the causal factors for nitrous oxide formation: in case of dominant reduction of soil $\mathrm{NO}_{3}^{-}$(uptake, immobilization) and/or drying of the top soil by plant water extraction, a reduction of $\mathrm{N}_{2} \mathrm{O}$ fluxes compared to fallow can be expected. On the contrary, whenever the dominant cover crop effects are addition of easily decomposable carbon, quick $\mathrm{N}$ release from fresh residues and/or higher top soil moisture under surface mulch residues, a temporal increase of losses can be caused. In this context, the interannual variability in weather conditions adds complexity to the cover crop effect. The overall effect will be reduced in years with adverse autumn conditions, leading to lower cover crop biomass compared to this study. Warmer spring temperatures than in this experiment may enhance an early cover crop turnover. In sub-humid Eastern Austria, the influence of spring-drought with subsequent wetting of the soil can constitute a special case for residue turnover to be studied.
As expected, our results showed a positive effect of soil water content on $\mathrm{N}_{2} \mathrm{O}$ emissions. A strong increase of losses, exceeding the background emissions of $5 \mu \mathrm{g} \mathrm{m}^{2} \mathrm{~h}^{-1}$, was observed at $>60 \%$ water filled porosity. Soil mineral $\mathrm{N}$ did not show a significant relation to $\mathrm{N}_{2} \mathrm{O}$ fluxes. At the time of highest $\mathrm{N}_{2} \mathrm{O}$ emissions (Lichtenwörth February; Pötting March), the soil $\mathrm{N}$ content was significantly lower in bare soil $\left(11.4 \mathrm{~kg} \mathrm{~N} \mathrm{ha}^{-1} ; 22.3 \mathrm{~kg} \mathrm{~N} \mathrm{ha}^{-1}\right)$ compared to the cover cropped plots (24.9 $\mathrm{kg} \mathrm{N} \mathrm{ha}^{-1} ; 37.4 \mathrm{~kg} \mathrm{~N}^{-1}$ ). Still, this does not explain the distinctive behavior of mustard, which did not differ from other cover crops in soil mineral N. The highest $\mathrm{R}^{2}$ among the tested causal factors for $\mathrm{N}_{2} \mathrm{O}$ was found for DOC. Also, Mitchell et al. (2013) showed that mineralizable $\mathrm{C}$ input from cover crop residue can control $\mathrm{N}_{2} \mathrm{O}$ emissions in case of sufficient availability of $\mathrm{NO}_{3}^{-}$. For the distinctive behavior of mustard, furthermore, the higher biomass $\mathrm{N}$-content of residues (cf. Figure 9) and their chemical composition has to be taken into account. 


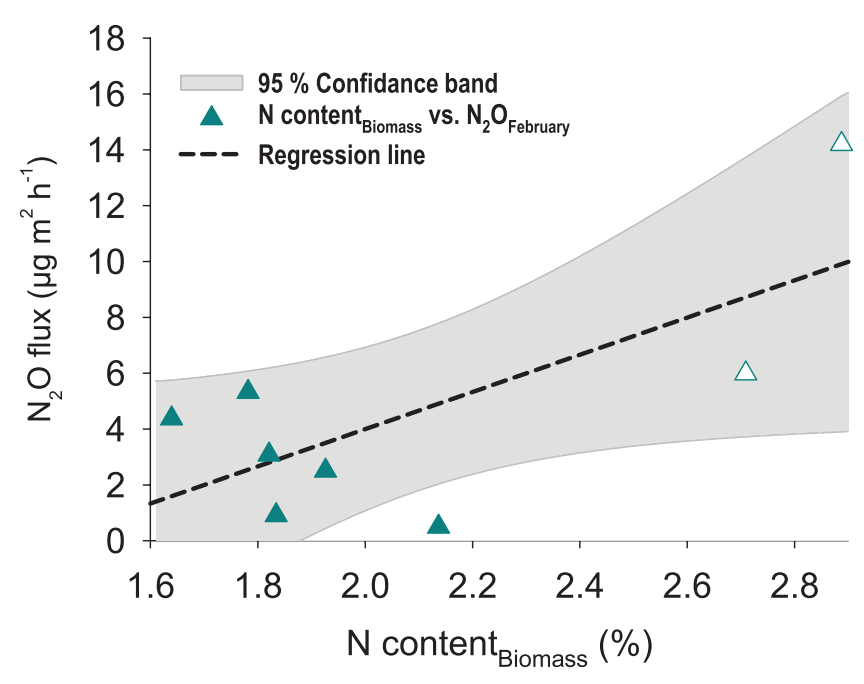

Figure 9. Relation between $\mathrm{N}$ content of cover crop biomass and $\mathrm{N}_{2} \mathrm{O}$ emissions. Data of the two experimental sites are pooled together. (Mustard variants are highlighted with white colored triangles.)

Abbildung 9. Beziehung zwischen N-Gehalt der Zwischenfrucht-Biomasse und den $\mathrm{N}_{2} \mathrm{O}$-Emissionen. Daten der zwei Versuchsstandorte sind gemittelt. (Senf-Varianten sind durch weiß gefüllte Dreiecke hervorgehoben.)

$\mathrm{CO}_{2}$ emissions were significantly related to soil mineral $\mathrm{N}$ at Pötting and soil water content at Lichtenwörth. $\mathrm{CO}_{2}$ and $\mathrm{N}$ release occur within the same process of organic matter mineralization. Therefore, it is difficult to prove if the relation between soil mineral $\mathrm{N}$ and $\mathrm{CO}_{2}$ is causal (enhanced microbial activity via otherwise limiting soil $\mathrm{N}$ ), or coincidental (two parameters expressing the same process). The relation to soil water content at Lichtenwörth indicates that the average saturation level at this site was still favorable for aerobic processes. The equally positive relation to $\mathrm{N}_{2} \mathrm{O}$ points to the role of anaerobic microsites in a soil with otherwise sufficient air-filled porosity at larger representative elementary volume.

\section{Conclusions}

Soil greenhouse gas emissions $\left(\mathrm{N}_{2} \mathrm{O}, \mathrm{CO}_{2}\right)$ were compared between different cover crops and fallow at two climatically different sites in Austria. The focus was on hot moments of high denitrification potential in the period between late autumn cover crop residue addition and early spring snow melting. The main conclusions of this study are:

(i) Overall $\mathrm{N}_{2} \mathrm{O}$ emissions between late autumn and early spring are low compared to the management impacts

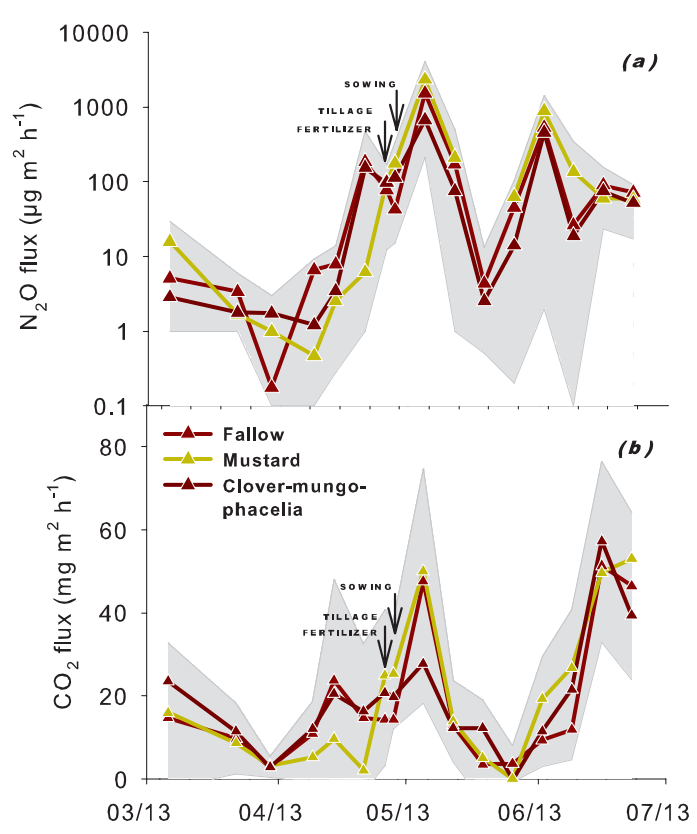

Figure 10. Time series of $\mathrm{N}_{2} \mathrm{O}$ (a) and $\mathrm{CO}_{2}$ (b) emissions following cover crops at the humid experimental site (Pötting, OÖ) Abbildung 10. Zeitreihe der $\mathrm{N}_{2} \mathrm{O}$ (a) und $\mathrm{CO}_{2}$ (b) Emissionen nach Zwischenfrucht auf dem humiden Standort (Pötting, OÖ)

(tillage, $\mathrm{N}$ fertilization) during the main crop vegetation period in spite of temporally high soil water content and freezing-thawing.

(ii) $\mathrm{N}_{2} \mathrm{O}$ emissions are increased by a mustard cover crop in pure stand, particularly for situations with high emission potential. It is suggested that high biomass $\mathrm{N}$ content and the specific biochemistry of mustard residues (glucosinolate decomposition) are the main reason for the enhanced $\mathrm{N}_{2} \mathrm{O}$ emissions. Cover crops increase $\mathrm{CO}_{2}$ flux reflecting an enhanced soil biological activity after addition of easily decomposable organic carbon. These gaseous $\mathrm{C}$ losses follow the previous $\mathrm{C}$ addition, which is not the case for $\mathrm{CO}_{2}$ emissions from fallow soil.

(iii) Soil water content $\left(\mathrm{N}_{2} \mathrm{O}\right)$, soil temperature $\left(\mathrm{CO}_{2}\right)$ and dissolved organic carbon $\left(\mathrm{N}_{2} \mathrm{O}\right.$ and $\left.\mathrm{CO}_{2}\right)$ were the dominant causal factors for greenhouse gas emissions. Particularly DOC is suggested as an appropriate indicator for cover crop induced ecosystem dynamics related to the carbon and nitrogen cycle.

From these findings, it is suggested that cover cropping as an agro-environmental measure does not compromise climate change mitigation in agriculture. However, brassica species in pure stand should be substituted by mixtures with lower seeding density of the brassica component. Integration of empirical evidence into modelling 
could contribute to management recommendations (plant type, seeding date) optimizing those factors related to cover cropping that are minimizing or even contributing to mitigation of greenhouse gas losses from agricultural fields. Further research is required to extend the obtained knowledge on cover crop effects on greenhouse gas emissions towards a broader range of possible environmental situations interacting with species' composition in residue turnover dynamics.

\section{Acknowledgement}

This study was performed in the framework of StartClim2012 (Project StartClim2012 A.) and financially supported by the Austrian Federal Ministry of Agriculture, Forestry, Environment and Water Management (BMLFUW), the Federal Minister of Science and Research (BMWF), the Federal state of Upper Austria (Land Oberösterreich) and the Austrian Federal Forests (Österreichischen Bundesforste).

\section{References}

Annicchiarico, P. (1997): Joint regression vs AMMI analysis of genotype-environment interactions for cereals in Italy. Euphytica 94, 53-62.

Arcara, P.G., Gamba, C., Bidini, D. and R. Marchetti (1999): The effect of urea and pig slurry fertilization on denitrification, direct nitrous oxide emission, volatile fatty acids, water-soluble carbon and anthrone-reactive carbon in maize-cropped soil from the Po plain (Modena, Italy). Biology and Fertility of Soils 29, 270-276.

Aulakh, M.S., Doran, J.W., Walters, D.T. and J.F. Power (1991): Legume residue and soil water effects on denitrification in soils of different textures. Soil Biology and Biochemistry 23, 1161-1167.

Baggs, E.M., Watson, C.A. and R.M. Rees (2000): The fate of nitrogen from incorporated cover crop and green manure residues. Nutrient cycling in agroecosystems 56, 153-163.

Basche, A.D. and F.E. Miguez (2012): Do cover crops decrease or increase nitrous oxide emissions? A metaanalysis. ASA, CSSA and SSSA Annual Meeting, Cincinnati, $\mathrm{OH}$, Abstract $\mathrm{N}^{\circ} 143-20$.

Bavin, T.K., Griffis, T.J., Baker, J.M. and R.T. Venterea (2009): Impact of reduced tillage and cover cropping on the greenhouse gas budget of a maize/soybean rotation ecosystem. Agriculture, Ecosystems and Environment 134, 234-242.

Creamer, N.G., Bennett, M.A. and B.R. Stinner (1997): Evaluation of cover crop mixtures for use in vegetable production systems. HortScience 32, 866-870.

Dabney, S.M. (1998): Cover crop impacts on watershed hydrology. Journal of Soil and Water Conservation 53, 207-213.

EU (2013): Regulation (EU) No 1305/2013 of the European Parliament and of the Council of 17 December 2013 on support for rural development by the European Agricultural Fund for Rural Development (EAFRD) and repealing Council Regulation (EC) No 1698/2005. Official Journal of the European Union L 347/487.

Fahey, J.W., Zalcmann, A.T. and P. Talalay (2001): The chemical diversity and distribution of glucosinolates and isothiocyanates among plants. Phytochemistry 56, 5-51.

Flessa, H., Ruser, R., Dörsch, P., Kamp, T., Jimenez, M. A., Munch, J.C. and F. Beese (2002): Integrated evaluation of greenhouse gas emissions $\left(\mathrm{CO}_{2}, \mathrm{CH}_{4}, \mathrm{~N}_{2} \mathrm{O}\right)$ from two farming systems in southern Germany. Agriculture, Ecosystems \& Environment 91, 175-189.

Gomes, J., Bayer, C., de Souza Costa, F., de Cássia Piccolo, M., Zanatta, J.A., Vieira, F.C.B. and J. Six (2009): Soil nitrous oxide emissions in long-term cover crops-based rotations under subtropical climate. Soil and Tillage Research 106, 36-44.

Hagedorn, F., Bellamy, P., Jandl, R., Rodeghiero, M. and M. Olsson (2011): Hot spots and hot moments for greenhouse gas emissions from soils. In: Jandl, R., Rodeghiero M. and M. Olsson (Eds): Soil Carbon in Sensitive European Ecosystems: From Science to Land Management, John Wiley \& Sons, Ltd, Chichester, UK, pp. 13-32.

Hartwig, N.L. and H.U. Ammon (2002): Cover crops and living mulches. Weed Science 50, 688-699.

IPCC (2007): Climate Change: Mitigation. Contribution of Working Group III to the Fourth Assessment Report of the Intergovernmental Panel on Climate Change, Chapter 8: Agriculture. Cambridge University Press, Cambridge, United Kingdom and New York, NY, USA. Jacinthe, P.A. and W.A. Dick (1997): Soil management and nitrous oxide emissions from cultivated fields in southern Ohio. Soil and Tillage Research 41, 221-235.

Jarecki, M.K., Parkin, T.B., Chan, A.S.K., Kaspar, T.C., Moorman, T.B., Singer, J.W., Kerr, B.J., Hatfield, J.L. 
and R. Jones (2009): Cover crop effects on nitrous oxide emission from a manure-treated Mollisol. Agriculture, Ecosystems and Environment 134, 29-35.

Kallenbach, C.M., Rolston, D.E. and W.R. Horwath (2010): Cover cropping affects soil $\mathrm{N}_{2} \mathrm{O}$ and $\mathrm{CO}_{2}$ emissions differently depending on type of irrigation. Agriculture, Ecosystems and Environment 137, 251-260.

Klik, A. and J. Eitzinger (2010): Impact of climate change on soil erosion and the efficiency of soil conservation practices in Austria. Journal of Agricultural Sciences 148, 529-541.

Kong, A.Y., Six, J., Bryant, D.C., Denison, R.F. and C. van Kessel (2005): The relationship between carbon input, aggregation, and soil organic carbon stabilization in sustainable cropping systems. Soil Science Society of America Journal 69, 1078-1085.

Lal, R. (2011): Sequestering carbon in soils of agro-ecosystems. Food Policy 36, S33-S39.

Lal, R., Kimble, J.M., Follett, R.F. and C.V. Cole (1998): The Potential of US Cropland to Sequester Carbon and Mitigate the Greenhouse Effect. Ann Arbor Press, Chelsea, MI, 128 pp.

Liebig, M.A., Tanaka, D.L. and J.R. Gross (2010): Fallow effects on soil carbon and greenhouse gas flux in Central North Dakota. Soil Science Society of America Journal 74, 358-365.

Magid, J., Luxhøi, J. and O.B. Lyshede (2004): Decomposition of plant residues at low temperatures separates turnover of nitrogen and energy rich tissue components in time. Plant and Soil 258, 351-365.

McSwiney, C.P., Snapp, S.S. and L.E. Gentry (2010): Use of $\mathrm{N}$ immobilization to tighten the $\mathrm{N}$ cycle in conventional agroecosystems. Ecological Applications 20, 648-662.

Meyer, L.D., Dabney, S.M., Murphree, C.E., Harmon, W.C. and E.H. Grissinger (1999): Crop production systems to control erosion and reduce runoff from upland silty soils. Transactions of the ASAE 42, 1645-1652.

Mitchell, D.C., Castellano, M.J., Sawyer, J.E. and J. Pantoja (2013): Cover Crop Effects on Nitrous Oxide Emissions: Role of Mineralizable Carbon. Soil Science Society of America Journal 77, 1765-1773.

ÖNORM (2012): ÖNORM L 1091: Chemische Bodenuntersuchungen - Bestimmung von mineralischem Stickstoff durch Extraktion mit Calciumchloridlösung - Nmin-Methode. Österreichisches Normungsinstitut, Wien.
Parkin, T.B. (1987): Soil microsites as a source of denitrification variability. Soil Science Society of America Journal 51, 1194-1199.

Parkin, T.B., Kaspar, T.C. and J.W. Singer (2006): Cover crop effects on the fate of $\mathrm{N}$ following soil application of swine manure. Plant and Soil 289, 141-152.

Pattey, E., Blackburn, L.G., Strachan, I.B., Desjardins, R. and D. Dow (2008): Spring thaw and growing season $\mathrm{N}_{2} \mathrm{O}$ emissions from a field planted with edible peas and a cover crop. Canadian Journal of Soil Science 88, 241-249.

Petersen, S.O., Mutegi, J.K., Hansen, E.M. and L.J. Munkholm (2011): Tillage effects on $\mathrm{N}_{2} \mathrm{O}$ emissions as influenced by a winter cover crop. Soil Biology and Biochemistry 43, 1509-1517.

Piepho, H.P., Büchse A. and C. Richter (2004): A mixed modelling approach for randomized experiments with repeated measures. Journal of Agronomy and Crop Science 190, 230-247.

Puget, P. and L.E. Drinkwater (2001): Short-term dynamics of root- and shoot derived carbon from a leguminous green manure. Soil Science Society of America Journal 65, 771-779.

Rochette, P., Gregorich, E.G. and R.L. Desjardins (1992): Comparison of static and dynamic closed chambers for measurement of soil respiration under field conditions. Canadian Journal of Soil Sciences 72, 605-609.

Rosecrance, R.C., Mccarty, G.W., Shelton, D.R. and J.R. Teasdale (2000): Denitrification and N mineralization from hairy vetch (Vicia villosa Roth) and rye (Secale cereale $\mathrm{L}$.) cover crop monocultures and bicultures. Plant and Soil 227, 283-290.

Sanz-Cobena, A., García-Marco, S., Quemada, M., Gabriel, J.L., Almendrosa, P. and A. Vallejo (2014): Do cover crops enhance $\mathrm{N}_{2} \mathrm{O}, \mathrm{CO}_{2}$ or $\mathrm{CH}_{4}$ emissions from soil in Mediterranean arable systems? Science of the Total Environment 466-467, 164-174.

Shepherd, M.A. and J. Webb. (1999): Effects of overwinter cover on nitrate loss and drainage from a sandy soil: consequences for water management? Soil Use and Management 15, 109-116.

Smith, P., Martino, D., Cai, Z., Gwary, D., Janzen, H., Kumar, P., McCarl, B., Ogle, S., O’Mara, F., Rice, C., Scholes, B., Sirontenko, O., Howden, M., McAllister, T., Pan, G., Romanenkov, V., Schneider, U., Towprayoon, S., Wattenbach M. and J. Smith (2008): Greenhouse gas mitigation in agriculture. Philosophical 
Transactions of the Royal Society B: Biological Sciences 363, 789-813.

Snapp, S.S., Swinton, S.M., Labarta, R., Mutch, D., Black, J.R., Leep, R., Nyiraneza, J. and K. O’Neil (2005): Evaluating cover crops for benefits, costs and performance within cropping system niches. Agronomy Journal 97, 322-332.

van Dam, A. (2006): Understanding the reduction of nitrogen leaching by catch crops. Published PhD Thesis, Wageningen University, Wageningen, $171 \mathrm{pp}$.

Velthof, G.L., Kuikman, P.J. and O. Oenema (2002): Nitrous oxide emission from soils amended with crop residues. Nutrient Cycling in Agroecosystems 62, 249-261.

Wagner-Riddle, C. and G.W. Thurtell (1998): Nitrous oxide emissions from agricultural fields during winter and spring thaw as affected by management practices. Nutrient Cycling in Agroecosystems 52, 151-163.

Wyland, L.J., Jackson, L.E., Chaney, W.E., Klonsky, K., Koike S.T. and B. Kimple (1996): Winter cover crops in a vegetable cropping system: Impacts on nitrate leaching, soil water, crop yield, pests and management costs. Agriculture, Ecosystems \& Environment 59, 1-17.

Yao, Z., Wolf, B., Chen, W., Butterbach-Bahl, K., Brüggemann, N., Wiesmeier, M., Dannenmann, M., Blank B. and Z. Zheng (2010): Spatial variability of $\mathrm{N}_{2} \mathrm{O}, \mathrm{CH}_{4}$ and $\mathrm{CO}_{2}$ fluxes within the Xilin River catchment of Inner Mongolia, China: a soil core study. Plant and Soil 331, 341-359. 